The Netherlands

\title{
Leveraging student-led interviews in the multilingual workplace
}

Jacobs, G.; Vandendaele, A.; Decock, S.

\section{Citation}

Jacobs, G., \& Vandendaele, A. (2021). Leveraging student-led interviews in the multilingual workplace. In S. Decock (Ed.), Communicating in Professions and Organizations (pp. 141-165). Cham: Palgrave Macmillan. doi:10.1007/978-3-030-61757-8_6

Version: $\quad$ Publisher's Version

License: Licensed under Article 25fa Copyright Act/Law (Amendment Taverne)

Downloaded from: $\quad$ https://hdl.handle.net/1887/3217318

Note: To cite this publication please use the final published version (if applicable). 


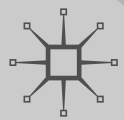

\section{Good Data in Business and Professional Discourse Research and Teaching Further Explorations}

\section{Edited by Geert Jacobs · Sofie Decock}

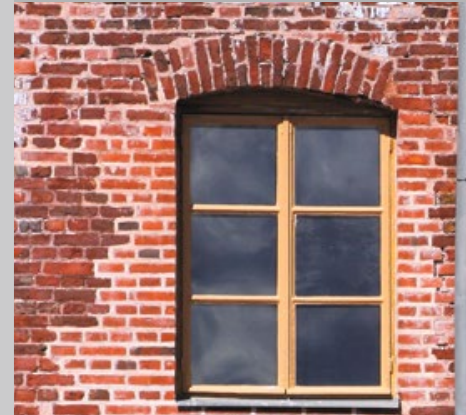

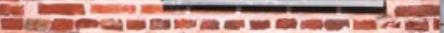

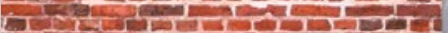

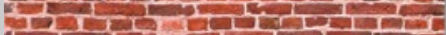

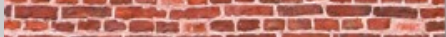

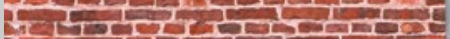

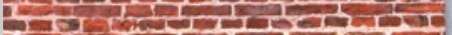
Se

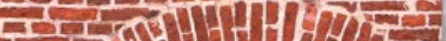

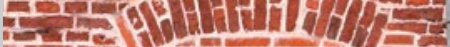

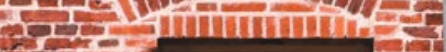
ric

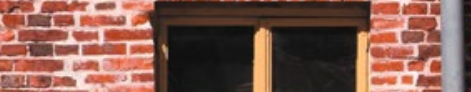

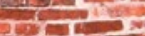
$-y^{2}-10$ (1)

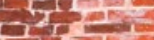

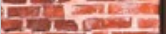

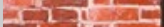

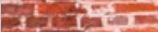
Iteris $\operatorname{lom}^{2}=0$

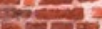
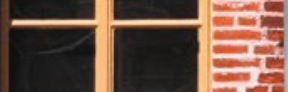
푸눌

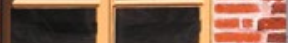
$\sqrt{2}=$ ب

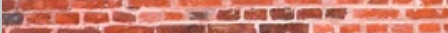

2.

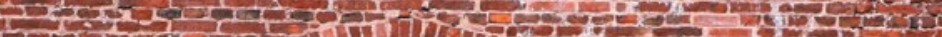

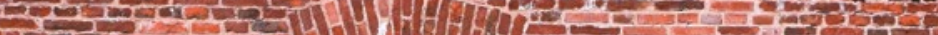

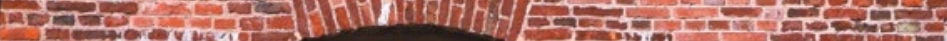

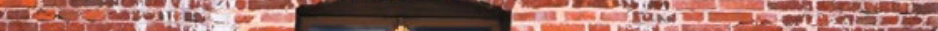

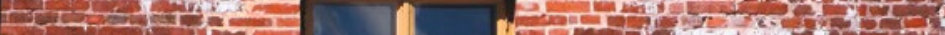

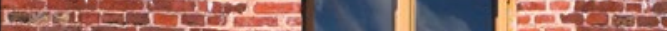

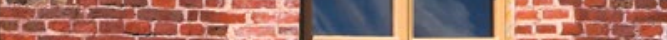

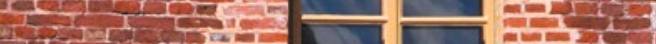

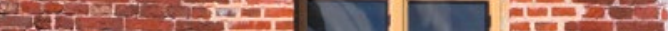

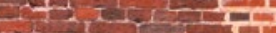

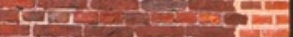

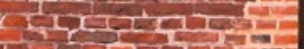

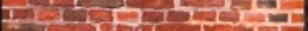

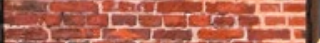

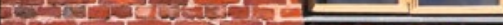
(a)

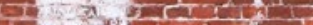

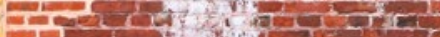

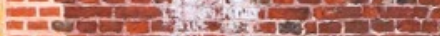

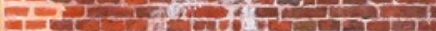

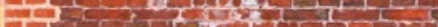

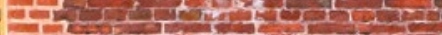

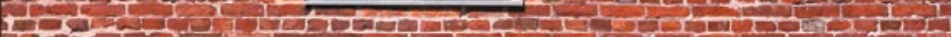
Pe La rom

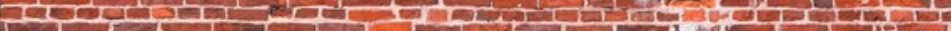

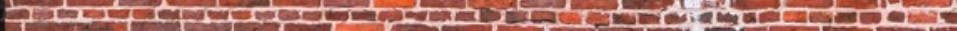

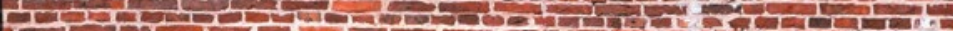

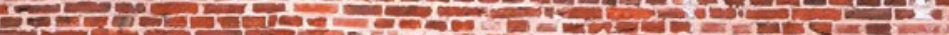

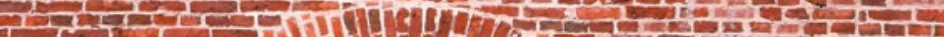

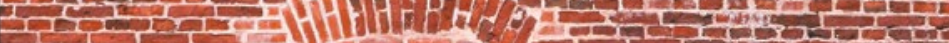
Ara

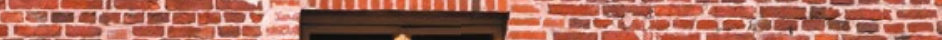

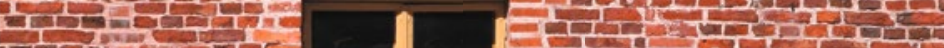

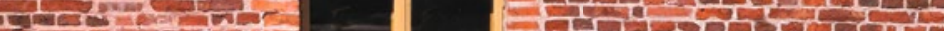

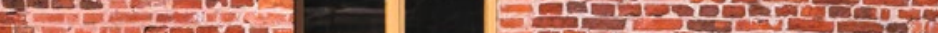

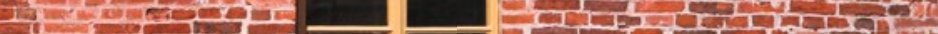

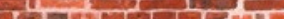

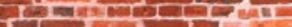
$x_{1}$

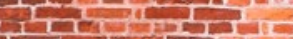

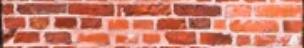

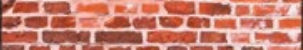

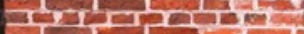

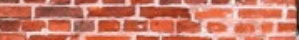

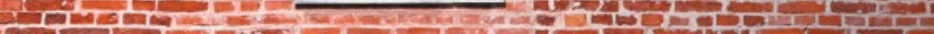

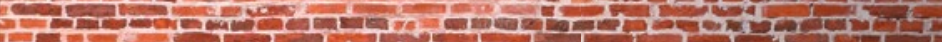


Communicating in Professions and Organizations

\author{
Series Editor \\ Jonathan Crichton \\ University of South Australia \\ Adelaide, SA, Australia
}


This ground-breaking series is edited by Jonathan Crichton, Senior Lecturer in Applied Linguistics at the University of South Australia. It provides a venue for research on issues of language and communication that matter to professionals, their clients and stakeholders. Books in the series explore the relevance and real world impact of communication research in professional practice and forge reciprocal links between researchers in applied linguistics/ discourse analysis and practitioners from numerous professions, including healthcare, education, business and trade, law, media, science and technology.

Central to this agenda, the series responds to contemporary challenges to professional practice that are bringing issues of language and communication to the fore. These include:

- The growing importance of communication as a form of professional expertise that needs to be made visible and developed as a resource for professionals

- Political, economic, technological and social changes that are transforming communicative practices in professions and organisations

- Increasing mobility and diversity (geographical, technological, cultural, linguistic) of organisations, professionals and clients

Books in the series combine up to date overviews of issues of language and communication relevant to the particular professional domain with original research that addresses these issues at relevant sites. The authors also explore the practical implications of this research for the professions/organisations in question.

We are actively commissioning projects for this series and welcome proposals from authors whose experience combines linguistic and professional expertise, from those who have long-standing knowledge of the professional and organisational settings in which their books are located and joint editing/authorship by language researchers and professional practitioners.

The series is designed for both academic and professional readers, for scholars and students in Applied Linguistics, Communication Studies and related fields, and for members of the professions and organisations whose practice is the focus of the series.

More information about this series at http://www.palgrave.com/gp/series/14904 
Geert Jacobs - Sofie Decock Editors

Good Data in Business and Professional Discourse Research and Teaching

Further Explorations

\section{palgrave macmillan}


Editors

Geert Jacobs

Department of Linguistics

Ghent University

Ghent, Belgium
Sofie Decock

Department of Translation, Interpreting

and Communication

Ghent University

Ghent, Belgium

Communicating in Professions and Organizations

ISBN 978-3-030-61756-1 ISBN 978-3-030-61757-8 (eBook)

https://doi.org/10.1007/978-3-030-61757-8

(C) The Editor(s) (if applicable) and The Author(s) 2021

This work is subject to copyright. All rights are solely and exclusively licensed by the Publisher, whether the whole or part of the material is concerned, specifically the rights of translation, reprinting, reuse of illustrations, recitation, broadcasting, reproduction on microfilms or in any other physical way, and transmission or information storage and retrieval, electronic adaptation, computer software, or by similar or dissimilar methodology now known or hereafter developed.

The use of general descriptive names, registered names, trademarks, service marks, etc. in this publication does not imply, even in the absence of a specific statement, that such names are exempt from the relevant protective laws and regulations and therefore free for general use.

The publisher, the authors and the editors are safe to assume that the advice and information in this book are believed to be true and accurate at the date of publication. Neither the publisher nor the authors or the editors give a warranty, expressed or implied, with respect to the material contained herein or for any errors or omissions that may have been made. The publisher remains neutral with regard to jurisdictional claims in published maps and institutional affiliations.

Cover illustration: Christian Wagner / Alamy Stock Photo

This Palgrave Macmillan imprint is published by the registered company Springer Nature Switzerland AG. The registered company address is: Gewerbestrasse 11, 6330 Cham, Switzerland 


\section{Praise for Good Data in Business and Professional Discourse Research and Teaching}

"This collection expertly balances interdisciplinary approaches, hands-on fieldwork, and academic rigour. The contributors team up to provide an ambitious and engaging, multifaceted exploration of the role of data in business and professional communication. This collection nicely advances common ground between researchers and practitioners and will provide authoritative insights for all interested in the role of language and communication in business or professional settings."

—Glen Michael Alessi, University of Modena and Reggio Emilia, Italy

"A timely, ground-breaking volume relying on a fundamental question- "What counts as data?"- as the focus for a broad-based study of business and professional discourse. The result is an enhanced understanding of the importance of organizational contexts in multilingual environments, which requires an expansion of data collection and analysis beyond traditional boundaries and demonstrates innovative uses of qualitative research."

—James M. Dubinsky, Rhetoric \& Writing, Virginia Tech, Past President \& Executive Director, Association for Business Communication $(A B C)$ 


\section{Contents}

1 What Counts as Good Data in Business and Professional Discourse Research and Training?

Sofie Decock and Geert Jacobs

2 Workplace Research and Applications in Real World Contexts: The Case of the Wellington Language in the Workplace Project

Janet Holmes and Bernadette Vine

3 What Is Professional in a Professional Magazine? Using Corpus Analysis to Identify Specializedness in Professional Discourse and Culture

Fanny Domenec and Philippe Millot

4 Researching Trust in Business Partnerships: Reflections on Data Collection and Positionality Christina Efthymiadou 
5 Measuring Competence for Global Business: In Search of Authentic Data in Japanese Business Corporations

Hiromasa Tanaka

6 Leveraging Student-Led Interviews in the Multilingual Workplace

Geert Jacobs and Astrid Vandendaele

7 Coworking: A Rhetorical Enterprise Situated in Place

Deborah C. Andrews

Index 


\section{Notes on Contributors}

Deborah C. Andrews is Professor of English, Emerita, and former director of the Center for Material Culture Studies at the University of Delaware, USA. She has published several articles, book chapters, and textbooks on business, professional and technical communication, especially in the international community.

Fanny Domenec is a Senior Lecturer at Paris 2 University. She teaches English for economics and finance. Her research work focuses on corporate discourse and culture in contexts of crisis. She also works on evolutions linked to ethics in the professional world (new discursive genres, professions or legal structures).

Janet Holmes is Emeritus Professor of Linguistics and Associate Director of the Wellington Language in the Workplace project. She researches in the area of sociolinguistics, specialising in workplace discourse and language and gender. With the Language in the Workplace team, she is currently investigating workplace discourse of relevance to migrants.

Philippe Millot is a Senior Lecturer in English for Specific Purposes at the University of Lyon (Jean Moulin, Lyon 3). His research interests include ESP, specialised domains and corpus linguistics. His research more particularly focuses on business and professional discourse analysis. $\mathrm{He}$ is also the associate editor of $A S p$, the French journal of ESP. 
Sofie Decock is Associate Professor at the Department of Translation, Interpreting and Communication at Ghent University, Belgium. She conducts research in the fields of business communication and German Studies with a focus on discourse, (intercultural, digital) interactions and persuasion.

Christina Efthymiadou is a Lecturer in International Management at Bristol Business School. She holds a PhD in Intercultural Communication from the University of Warwick and her main research interests include the construction and negotiation of identity, professional discourse and culture. Christina adopts ethnographic methods and works mainly with interactional data.

Geert Jacobs is a Professor of English for Specific Purposes and Business Discourse at the Department of Linguistics at Ghent University. He has researched wide-ranging forms of institutional interaction and of news text and talk.

Hiromasa Tanaka Ed. D is a Professor at International Studies Department, School of Humanities, Meisei University, Japan. He teaches research methodology courses for graduate students, and project-based courses for undergraduate students. As a consultant, Hiromasa has been involved a number of human resource development system design for business corporations.

Astrid Vandendaele is an Assistant Professor of Journalism and New Media at Leiden University. Her research focuses on news production processes as well as communication processes in an institutional context from a linguistic ethnographic perspective. She teaches courses in Journalism and New Media at Leiden University as well as Business and Scientific Communication at Ghent University.

Bernadette Vine is Senior Researcher and Corpus Manager for the Wellington Language in the Workplace Project (www.victoria.ac.nz/ $\mathrm{lwp} /$ ). Bernadette's research interests include workplace communication, leadership and New Zealand English. Her publications include her recent textbook, Introducing Language in the Workplace (Cambridge University Press, 2020). 


\title{
6
}

\section{Leveraging Student-Led Interviews in the Multilingual Workplace}

\author{
Geert Jacobs and Astrid Vandendaele
}

For those interested in studying the role of language and communication in business and the professions, few settings can be more inspiring than the multilingual workplace. Whether we are looking at an international arts centre, a big multinational corporation with branches across the globe or an ambitious high-tech start-up, the series of relevant research questions is endless: which (foreign) languages are used for which purposes? What level of proficiency is expected? How are newcomers screened and trained? What are the costs and benefits of multilingualism? But also, from a theoretical and methodological point of view: how can we find an answer to these and many other questions? And, finally, zooming in even further, and chiming in with the overall issues that this book is concerned with, what kind of data can and/or should we get hold of in trying to answer these questions?

\footnotetext{
G. Jacobs $(\bowtie) \cdot$ A. Vandendaele

Department of Linguistics, Ghent University, Ghent, Belgium e-mail: geert.jacobs@ugent.be; astrid.vandendaele@ugent.be 
Following up on our earlier case-based explorations of the complex interactions between learning, research, and practice in the field of business and professional communication (Bruyer et al. 2016; Vandendaele et al. 2016), this chapter raises a number of questions on the use of collective data-gathering techniques as part of a wider, multi-site study on the multilingual workplace. Our dataset consists of the transcripts of the audio recordings of 65 semi-structured interviews conducted by graduate students of business communication in the organizations where they were about to start their traineeships (including corporate and non-profit settings and ranging from small start-ups to long-established multidepartment companies). All 65 interviews focus on multilingual communicative practices in 65 different workplaces in Belgium, a country with three official languages, which allows us to gain substantial insight into the complexity of those practices. Through qualitative discursive analysis of the interview transcripts, we set out to identify a number of shared professional views on and practical applications of multilingualism. In particular, we will demonstrate how multilingualism is embraced as a strategic asset within the broader framework of glocalization and multinational marketing. In addition, whereas multilingualism is invariably encouraged 'on the shop floor' in an informal context, our findings show that there are formal policies regulating and restricting its use and that they vary greatly from organization to organization.

With a view to this volume's central question "What counts as data?" our analysis goes on to shed interesting new light on the affordances of collective data-gathering. Focusing on inter-interviewer variation, we take into account three recurring parameters (agency, lexical choices and formality) to identify three distinct interviewer personae in our dataset (viz. the Student, the Researcher and the Practitioner) as well as a number of complex patterns of role-switching and identity construction. We conclude the chapter by reflecting on the implications for the study of business and professional discourse and the roles of learners, scholars and practitioners in researching as well as providing training opportunities for the multilingual workplace and by presenting guidelines in order to strengthen interaction between these three sets of stakeholders. 


\section{Introduction}

It is well-known that the scholarship on business and professional discourse research is richly interdisciplinary, attracting researchers in applied linguistics and discourse studies as well as communication sciences, sociology, management, marketing and studies of information systems. Even if we restrict our scope to the niche of what has been labelled "language in the workplace", there is still incredible diversity as Vine's 2018 Handbook demonstrates. In terms of methodology, for example, the academic efforts in business and professional discourse studies can be linked up with such wide-ranging scholarly frameworks as Critical Discourse Analysis (Mayr 2008), genre studies (from meetings, Bargiela-Chiappini and Harris 1997, to press releases, Jacobs 1999), Conversation Analysis (see for example Drew and Heritage 1992 for a pioneering work as well as, more recently, Antaki 2011), ethnography (Rampton et al. 2004), corpus linguistics (Handford 2017), linguistic pragmatics (Östman and Verschueren 2011) and politeness theory (Haugh and Watanabe 2017), to name but a few of the many paradigms that have proved inspirational in this area. There is an even longer list of topics that have been addressed, including humour, emotions, conflict, power, culture, gender, leadership and storytelling.

What distinguishes research on business and professional discourse perhaps most from other scholarly endeavours in the realm of language and communication is the very thin line between practice and learning; i.e. we notice how, in this specific academic context, the boundary between practitioners in a professional setting and students in the classroom is crossed more easily. In fact, the complex interaction between workplace research, practice and learning has started to develop into an important and exciting object of scholarly attention in its own right. Sarangi and Candlin (2010), for example, have discussed the impact of inviting practitioners to the classroom in order to share their expertise in a specific field of interest. More recently, Drury-Grogan and Russ (2013) have looked at how to integrate simulations of real cases in pedagogical settings. As Blake (1991) indicated early on, the ultimate step in bridging the gap between learning and practice is to get students out of the 
classroom and provide them with opportunities to work with practitioners in the field. This includes, but is definitely not restricted to, foreign language learning and issues of language proficiency (see Kerekes 2017). In exploring these subjects, we start to come to grips with the multifaceted role that language and communication are playing in helping learners transition into practitioners. In a previous study, we explored how students struggle to forge a sustainable partnership with practitioners and to translate their academic research in useful and practice-driven recommendations, and we called for follow-up studies to redefine both the students' and the teachers' roles in the collaboration (Vandendaele et al. 2016). Focusing on student research projects commissioned by external organisations, we argued that students should be encouraged to take on an ethnographer's perspective, with an increased awareness of their unique insider position as 'junior consultants' for the organisations (see also Bruyer et al. 2016 for an earlier investigation of the interfaces between learning, research and practice via the analysis of a student research project on Corporate Social Responsibility (CSR) in the pharmaceutical industry).

In this chapter, we combine an interest in one of the traditional topics of workplace studies, viz. multilingualism (see Lüdi 2017), with close attention to the intriguing space between workplace learning, research and practice as we set about experimenting with collective data-gathering techniques in which our students negotiate hybrid researcher-practitionerlearner identities. Our dataset consists of the transcripts of the audio recordings of 65 semi-structured interviews conducted by graduate students of business communication in the organizations where they were about to start their traineeships (including corporate and non-profit settings and ranging from small start-ups to long-established multidepartment companies). The focus of the interviews is multilingual communicative practices in the workplace, but we also take advantage of the unusual setup to explore this volume's central question "What counts as data?", as well as reflect on the added benefits — and possible pitfallsof this collective data-gathering technique. 


\section{Case and Data}

The students who conducted the interviews under investigation were all enrolled in the master's program in Multilingual Business Communication (MBC) organized at Ghent University in Belgium. It is important to mention here that Belgium, a country with over 11 million inhabitants, is composed of three communities, each with a different language, i.e. French, Dutch and, to a lesser extent, German. The MBC students in our dataset are all Flemish, i.e. Dutch-speaking, with one exception: a Frenchspeaking student from Brussels. Coming from diverse academic backgrounds -including economics, literature and linguistics, communication sciences, law and political science-the students make up a heterogeneous community, combining wide-ranging theoretical knowledge and expertise with different sets of methodological research tools. The oneyear, 60-credit program helps them to acquire new practical skills as well as new theoretical knowledge in the field of business communication while also focusing on the 'multilingual' component with classes taught in English, French and Dutch.

One of the central principles underlying the program is a firm belief in the added value of the students' intensive interaction with practitioners. This takes many forms including simulation exercises, workshops led by communication professionals at their companies' premises, invited lectures by practitioners, a team-based research project commissioned by an outside organization and a 10-week traineeship at the end of the program. Each of these practice-driven assignments gives the students the opportunity to gain thorough hands-on experience with the challenges of business and professional communication in a real multilingual organizational setting. All of this has contributed to an interdisciplinary curriculum that aims to bridge the gap between learning and practice, to ease the transition from the university to the workplace. This is in line with the views of business communication students elsewhere in Europe as demonstrated by Aertsen et al. (2013), who argue that "one way out to address the expectations of both teaching staff and students is a teaching practice that helps students develop theoretically based practical skills" (322). 
As for the 10-week internships in our program, we consider them both as a direct gateway to the professional world and as a unique research opportunity. The double role of the internship is encapsulated in the fact that we advocate it as fieldwork experience, allowing for a combination of (reflexive) ethnography and (hands-on, action-oriented) practice.

The 65 interviews that constitute our dataset in this study were conducted by our students in the organizations where they were about to start their traineeships. These initial interactions can be seen as a first contact, with the students getting to know some of the people they will be working with, but also as a starting point for their research, exploring what multilingual issues might be worth further scholarly scrutiny during their traineeships. The interview guide that the students were encouraged to use was structured as follows (Fig. 6.1).

\section{Before the interview}

Announce the overall focus on multilingualism and identify the main topics. Ask to conduct the interview in the interviewee's preferred language

At the start of the interview

Introduce the objectives of the interview in relation to the traineeship and the research project. Ask for permission to record.

Part 1 of the interview: the interviewee's background (5 to $10 \mathrm{~min}$.)

Topics include: the interviewee's job description, professional experience, qualifications and training, and proficiency in foreign languages.

Part 2 of the interview: use of (foreign) languages in the organization (20 to $30 \mathrm{~min}$.)

Topics include: the use of (foreign) languages for specific purposes, media and genres, and with different stakeholders; organizational language policies; developments over time; quality control; recruitment practices. Part 3 of the interview: the interviewee's personal views on foreign languages in the organization (5 to $10 \mathrm{~min}$.)

Fig. 6.1 Structure of the interview guide 
In line with the requirements of semi-structured interviewing, the students were encouraged to ask broad, open-ended questions, go with the interviewee's flow and ask follow-up questions, encouraging the interviewees to provide illustrative anecdotes.

The resulting dataset comprises audio recordings and transcripts of 65 interviews, which lasted — on average_-about 30 minutes. The interviewers were all graduate students of multilingual business communication who were enrolled in two consecutive years of the same one-year program and had completed all of the curriculum's regular courses. Each student was about to start the traineeship and end-of-year research project. The interviewees were all in a communication-related position at a wide range of mostly Belgian organizations, including government, NGOs, arts, non-profit organizations, communication agencies, and private companies. The latter ranged from newly founded start-ups to long-established multi-department companies, some local, others multinational. Most interviews were conducted in Dutch, yet three of them were held in English, in accordance with the interviewee's preference/nationality, or in case of an internship abroad. In this chapter, we present the interview extracts in the original language, with translations in English for the Dutch-language extracts.

\section{Research Questions and Method}

Based on the case and dataset identified in the previous section, we set out to address the following two highly open-ended research questions:

RQ1: What can we learn from our data about multilingualism in the workplace?

RQ2: What can we learn about the process of data collection based on the interviews our students conducted at their internships? 
As for the first research question, through a qualitative content analysis of the interview transcripts, we set out to identify a number of dominant shared professional views on and practical applications of multilingualism. With a view to the second research question, we aim to contribute to this volume's focus on "What counts as data?" by looking at the affordances of collective data-gathering, e.g. does this technique have an effect on the quality of the data? Are there added benefits — or disadvantagescompared to single person data-gathering? In this part of our study, we rely on an analysis of (varying degrees of) agency, lexical patterns and register.

\section{Findings}

\section{Multilingualism}

\section{Multilingualism as an Enriching Opportunity}

Most if not all of the 65 interviewees in our dataset seem to embrace multilingualism as a very welcome condition that will have a positive impact on the organization. The active and widespread use of a range of different (foreign) languages, English and French in particular, is variously referred to as "an enriching opportunity", "added value", and "an asset".

\section{Extract $1^{1}$ :}

"omdat ik denk dat je niet alleen door de taal op zich en het vocabularium en de grammatica van de taal, maar ik denk ook dat de contacten die je kan krijgen met uhm mensen van andere nationaliteiten verrijkend zijn dus ik vind het sowieso los van dit bedriff vind ik het een grote meerwaarde zonder enige twijfel."

"because I think that you do not just because of the language as such and the grammar of the language, but I also think that the contact you can have with uhm people from different nationalities can be enriching, so, in any

\footnotetext{
${ }^{1}$ All excerpts have been anonymized. All transcripts are available upon request.
} 
case, apart from this company, I think it is a substantial added value without a doubt."

Extract 2:

"Eh dus ja, zeker een, een troef en een verrijking."

"Uhm so yes, definitely an asset and enriching."

It is a predominantly positive appreciation that echoes the findings from Angouri's (2013) analysis of language policy and language practice in one consortium of three multinational companies as well as Grin's (2013) claim that the spread of foreign language proficiency across workplaces constitutes substantial macro-economic value. The optimism that dominates our dataset seems to contrast with a long-standing dissident belief in the study of multilingualism in the workplace about "Babel in business" and language as a barrier in, for example, HQ-subsidiary relationships (Harzing et al. 2011).

As far as our data are concerned, it needs to be pointed out that the fact that we see multilingualism being embraced does not seem to be in conflict with a deep-rooted respect for the local language. This observation is in line with Ehrenreich's (2010) study of the role of English and other languages as perceived by members of upper management in a familyowned German multinational corporation in the technology sector. In this study she shows that, in the twenty-first century, English has become an indispensable "must" in the company but that, despite the dominance of English, other languages are not disappearing from the scene and continue to be used as a pragmatic or strategic resource. The fact that multilingualism is a "must", is something we encountered often in our data. One of the reasons stated has to do with the official language requirements of the Belgian context (Extracts 3 and 4). Moreover, the growing need for English as a Business Lingua Franca (BELF) in an international context, is also flagged up in the interviews (cf. Extract 4).

\section{Extract 3:}

"Frans in tweede instantie, dat is als business partner een must, back office wenselijk.... Ja, als je echt geen Frans kan, dan ga je volgens mij niet kunnen opstarten, omdat je altijd een telefoon in het Frans kan krijgen en als je dan niet de basisdienstverlening kan geven, dan is dat wel een issue. (...) Het is, 
momenteel, het speelt wel, als je het niet spreekt, ga je er volgens mij niet binnen geraken."

"French, in second place, that is a must for a business partner, highly recommended for back office ... Yes, if you don't speak any French, you won't be able to start in my opinion, because there's always the possibility of receiving a phone call in French and if you are then unable to offer basic service, then that's an issue. (...) It is, at the moment, it is an issue, if you don't speak it, I don't think you will get in."

Extract 4:

"De Nationale Loterij is een 100\% overheidsinstelling, waardoor het Nederlands, Frans uh ja ne must is voor ons, en daarnaast zitten we in een internationale sport context dus is het Engels ook belangrijk. We kunnen bijna niet anders dan onze communicatie in 3 talen voeren."

"The National Lottery is $100 \%$ a governmental institution, which makes Dutch, French uhm yes a must for us, and, next to that, we are also part of an international sports context, so English is important as well. We are almost forced to communicate in 3 languages."

The seemingly effortless combination of local and particular concerns with more global, universal ambitions that speaks from our data can be seen to tie in with the broader frameworks of glocalization and micromarketing in a multinational business perspective (Robertson 1994). It is in sharp contrast with the overriding sentiments in other societal domains, education in particular, where multilingualism is considered by many as a problem or even as a threat (see Mortensen's 2014 study for a nuanced case-based view of how the pro-English language ideology that is so widespread in higher education translates into practice-based language policies that turn out to be very different). It should be noted in this respect that our data are exclusively related to white-collar settings: typically, the interviews that our students conducted are with managers or senior office staff and so they may gloss over some of the more critical views about multilingualism that exist elsewhere in the workplace, especially in bluecollar environments (e.g. Lønsmann 2014).

Although a lot of the people interviewed in our data set react positively to multilingualism, it goes beyond appreciation of the concept; a number of them seem to be purposely seeking it out, trying to launch 
strategic partnerships with new suppliers and customers who speak a different language. The following extract from one of the interviews illustrates this very well:

\section{Extract 5:}

"Ja, eh, in principe, op dit moment werken hier een zes à acht mensen en die zijn allemaal Nederlandstalig maar, eh, wij werken wel, eh, een stukje bewust zelfs samen met, eh, anderstalige partners, leveranciers bedoel ik vooral, dat is vooral Frans, mensen uit het Brusselse, mensen uit Louvain-La-Neuve, en we hebben bewust ook voor hun gekozen om ons Frans hier een beetje op peil te houden, omdat wij op dit moment eigenlijk geen Franstalige klanten hebben, eh, maar wij, eh, wij willen die wel hebben, omdat ja, wij zijn een tweetalig land en als je nationale campagnes doet en wij hebben die in het verleden ook gedaan, dan willen wij met ons bureau, eh ja, ook wel nationale campagnes aankunnen. Dat is voor het Frans"

"Yes, uhm, in theory at the moment we have six to eight people working here and they are all Dutch-speaking but, uhm, we do work, uhm, deliberately in part with uhm foreign-language partners, I mean suppliers, especially French-speaking, people from around Brussels, from Louvain-laNeuve, and we chose them deliberately to kind of maintain our level of French here, seeing we don't have any French-speaking customers, uhm, but we do want them, because, yes, we are a bilingual country and if you create national campaigns which we did in the past, that means that we uhm yes want to manage with our agency. When it comes to French.”

Clearly, the interviewee in this extract indicates that it is important for his organization to position themselves as explicitly multilingual: it is an essential part of their corporate strategy.

\section{Multilingualism, Gatekeeping and Skillification}

For organizations that embrace multilingualism so unequivocally, it is not surprising to see that they insist on foreign language proficiency as one of the key gatekeeping criteria in selecting newcomers during the hiring process. The following extract is a fine illustration: 
Extract 6:

"Ja. Eh, eigenlijk, wat dat voor ons nodig is, is dat we altijd werken met mensen die heel goed Engels kunnen en minstens één andere Europese taal. Dus eh, Frans of eh, Duits, of eh, whatever. Eh, en die, eh, toch al tien of vijftien jaar ervaring hebben in de HR-sector in een Europees land. Eh, plus misschien buitenland. Dus eh, ja, want altijd als wij een job post hebben, gaan we altijd, altijd is er een korte uitleg en dan is het altijd: mijn languages are English, French, Dutch, of English, German, of English, dat. Dus, allez, er is altijd een minimum vereiste van twee talen in de meeste bedrijven. Of soms drie. Dus ja, talen is echt wel een must."

"Yes. Uhm, in fact, what we require, is we always work with people who speak English really well, and at least one other European language. So uhm French or uhm German or uhm whatever? Uhm, and people that, uhm have about ten to fifteen years of experience in HR in a European country. Uhm, plus maybe abroad. So uhm yes, because whenever we have a vacancy, we will always, there is always a brief job description, and it always states; my languages are English, French, Dutch, or English, German, or English, that, so, you know, there is always this minimum requirement of two languages in most companies. Or sometimes three. So yes, languages are an absolute must."

In this sense, our findings are in line with Peltokorpi and Vaara's (2014) work on so-called 'language-sensitive recruitment', which is identified as a key human resource management practice foregrounding foreign language competences and language use. They have demonstrated how taking a certain proficiency in one or more of the organization's foreign languages as a precondition for employment provides means for better communication and enhanced knowledge transfer, facilitates the development of international networks and makes it easier to bypass hierarchies.

Some of this has inspired a critical sociolinguistic perspective on the so-called 'commodification' of language. Heller (2010), for example, has written extensively about what she calls the "salience [of language] as a resource with exchange value" in the globalized new economy under the political economic conditions of late capitalism, in settings related to language teaching, translation, and performance art but also in tourism, marketing, and business communication (including, most prominently_iconically almost—, call centres). Related notions include 
skillification or skilling the self, as it was first presented in Allan's 2013 study of the key role of English in the communicability of immigrants as flexible labour, as well as language work (and the language worker); as for the latter, Thurlow's 2020 edited volume on "the business of words" makes a substantial contribution towards the 'high-end' wordsmithing practices of advertisers, public relations officers, dialect coaches and linguists whose talk and text gets "professionally designed, institutionally managed, and, inevitably, objectified for status and profit”.

\section{Regulating Multilingualism and the Belgian Situation}

Whereas multilingualism is invariably encouraged in the office, 'on the shop floor', in an informal context, our findings show that there are formal policies regulating and restricting its use and they vary greatly from organization to organization. The dividing line seems to be between internal and external communication, where the former seems free and intuitive, and mistakes don't matter as much, whereas the latter is rigid, strict, and controlled. The following extract exemplifies the loose, pragmatic attitude towards the use of foreign languages inside the organization:

\section{Extract 7:}

"Kijk mijn Frans, als je, als ik in het Frans een mail stuur naar onze Franse partner, tuurlijk gaan daar fouten in staan, eh. Het moet, eh, aanvaardbaar zijn en het moet begrijpbaar zijn, als je merkt dat het, eh, onbegrijpelijk is, dan moet je overschakelen, dan gaan we naar het Engels overschakelen."

"My French, you see, if you, if I send an email in French to our Frenchspeaking partner, of course there will be mistakes, uhm. It should be, uhm, acceptable and it must be understandable, if you notice that it, uhm, is incomprehensible, then you should switch, then we will switch to English.”

It echoes Angouri's (2013) analysis of language policy and language practice in one consortium of three multinational companies referred to above as it shows that the language policy in these multinationals is constructed as being flexible where both employees and managers typically 
take a 'what works' approach regarding language practice. Similarly Ehrenreich, in the 2010 study mentioned earlier, concluded when it came to English: "What needs to be learned, however, is not English as a native language but communicative effectiveness in English as a business lingua franca, which —as an international contact language-brings together non-native as well as native Englishes from various linguacultural backgrounds spoken with varying degrees of proficiency. Learning to cope with the challenges of such diversity, in the context of business communication, seems to happen most effectively in business "communities of practice" rather than in traditional English training".

In the Belgian multilingual workplace context, some of the linguistic choices are in fact determined by the government. "It's the law that determines the language we use", one of the interviewees comments, referring to the language legislation in Belgium. ${ }^{2}$ Below, we can see this exemplified at the communications office of a governmental organization in Flanders:

Extract 8:

"Ja in principe iedereen die hier een een openbare functie bekleedt of die direct contact heeft met de met de burger of mens die om om advies of wat dan ook komen vragen moeten altijd in het Nederlands te woord gestaan worden. Het gebeurt dat er mensen euhm op gesprek komen bij de schepen die het Nederlands niet machtig zijn en ik moet zeggen alhoewel dat dat dan officieel niet mag dan schakelen wij wel over allee of hij dan vooral maar naar het Frans is dat dan doorgaans"

"In theory, everyone who holds an official position or anyone who is in direct contact with the citizens, or a person who asks for advice or whatever, those people should always be addressed in Dutch. Once in a while, people uhm, who don't speak Dutch will visit the alderman and I have to admit that, even though it is not allowed officially, we will switch, or for the most part he will switch to, usually, French."

\footnotetext{
${ }^{2}$ According to Belgian language legislation, the language of official documents is determined by the linguistic region the company is in. Official (federal) documents should be written in the language spoken in that region. In Brussels, this means both French and Dutch. When it comes to various organizations, language policies have been decided on by the Flemish and the French Communities, each of them imploring organizations to communicate with staff in the language of the region.
} 
Most often, there is a lot of freedom in the actual multilingual practices, and the comments concerning English and French in the abovementioned extracts seem typical of the Belgian context, in which almost all of the interviews in this study were situated. English is considered "the default language when dealing with foreign-language speakers", but French is considered "crucial". "As a Belgian company, you cannot afford to not be able to speak French", one interviewee argues.

Some even go one step further and argue that multilingualism is "quintessentially Belgian" and it is linked to the organization's corporate values.

\section{Collective Data Gathering}

In this second part of the analysis, we turn to what we can learn about the process of collective data-gathering based on the interviews that our students conducted at their internships. As we mentioned above, as a guideline for the 65 student-led interviews, conducted by 65 different interviewees, we introduced a list of questions. This was meant to help compensate for the inevitable differences that could be expected. However, in spite of our efforts to make the dataset as uniform as possible, we did notice striking individual differences. Drawing on an analysis of (varying degrees of) agency, lexical patterns and register, our main finding is that we observed a lot of diversity in the form of inter-interviewer variation. In what follows, we set out to demonstrate how we believe the diversity we encountered can be captured in the following three interviewer personae:

1. The interviewer as student

2. The interviewer as researcher

3. The interviewer as practitioner

\section{The Interviewer as Student}

A first group of interviewers approached the informants very much from a student perspective, drawing on a typical school assignment vocabulary, displaying a high degree of formality and positioning themselves as data 
miners who had low agency and aimed at closely following the predetermined script. The "interviewer as student" persona is perfectly exemplified in Extract 9 when, in the opening moves, the interviewer talks about preparing a "dissertation" and writing up a "research proposal". At least on two occasions he mentions that he "has to" do this. Overall, he uses tentative language and sounds uncertain with lots of hesitations and a number of modal auxiliaries, as well as highly formal, like when he asks permission to record the interview.

In the next extract from another interview led by a different student we see a similar level of tentativeness when it comes to exploring possible topics for the research project that the student is meant to conduct during his traineeship.

Extract 9:

- IR: Wat ik juist misschien nog wou vragen, nu we het hierover gehad hebben, zijn er soms problemen of interessante invalshoeken die u ziet waarover u denkt van dat zou wel tof zijn als ik daarover zou schrijven? of ziet u niet direct...

- IE: Voor jouw thesis bedoel je?

- IR: Ja want het ding is wel, als het over die meertaligheid moeilijk is kan ik nog altijd een ander thema kiezen, maar in eerste instantie is het dus de bedoeling dat ik daarover (...) ik ga er sowieso zelf nog over nadenken maar het zou kunnen dat u zegt van dat is nu wel zo een probleem waarover misschien geschreven zou kunnen worden.

- IR: What I just wanted to maybe ask, now we talked about; are there sometimes problems or interesting perspectives you see, of which you think that it might be cool if I were to write about? Or can't you think of anythinhg right now...

- IE: For your dissertation, you mean?

- IR: Yes, because the thing is, if it's difficult to do it about that multilingualism, I can always choose another theme, but to start off I am supposed to write about (...) Anyway, I am going to think about it myself but it might be possible that you say well, that is such a problem that might be written about.

Note as well how the student addresses the interviewee using the Dutch pronoun ' $u$ ', i.e. the formal version for 'you', indicating a perceived difference in status. 


\section{The Interviewer as Researcher}

A second group of interviewers approached the informants from what can be seen as a researcher perspective, drawing on a scholarly vocabulary, displaying medium formality and a high degree of agency. The following is a good illustration:

Extract 10:

- IR: Mijn thesis zal gaan over meertaligheid en nu ben ik nog op zoek naar een invalshoek vanuit [de organisatie]. Daarbij moet ik weten wat uw functie en verantwoordelijkheden zijn, maar dat heeft $u$ al uitgelegd. Dus vroeg ik mij af wat eigenlijk het gebruik is van vreemde talen binnen [de organisatie]? Want bij mijn eerste gesprek met mevrouw xxx heb er al over gepraat en ze zei dat het moeilijk onderwerp zou zijn omdat [de organisatie] eigenlijk vooral Nederlandstalig is. Nu denk ik wel dat jullie toch hier en daar contact hebben met andere talen?

- IR: My thesis will be about multilingualism and and at the moment I am looking for a perspective from (company). For that reason, I need to know what your job and responsibilities are, but you have already explained that. So, I was wondering what the use of foreign languages is like at (company)? Because, during my first talk with Mrs XXX discusses this and she said it would be a difficult subject because (company) is actually mainly Dutchspeaking. Now I do believe that you do get in contact with other languages here and there?

There is a lot more confidence on the student's part in this extract, with hardly any hesitations. Her take on the research angle is a lot more scholarly than that in the extract quoted earlier. When the student says she 'needs to' know what the interviewee's job and responsibilities are, the obligation seems to lie with her: she wants to know what the interviewee does because it can lead her to a good research angle, not because she has been told by her teacher to inquire into this—or at least that is what she argues.

Here's a second example, with the interviewer exploring various research options in collaboration with the interviewee:

\section{Extract 11:}

- IR: Ja, maar inderdaad, ik kan dus ja met wat ik dit dit interview moet ik dan een soort van voorstel doen dat nog niet bindend is, maar van in welke richting ik zou willen verderwerken, dus ik denk dat wel iets nuttig kan zijn 
van die, ja, verschillende kanalen in crisiscommunicatie-setting, eh, hoe dat bedrijven dat dan doen. Ik heb nog niet (...)

- IE: Hoe dat ze binnen één taal fluctueren dan

- IR: ja, ja

- IE: en en welke talen behouden blijven op basis van welke criteria

- IR: ja

- IE: eh, wordt er dan gekeken naar uw volgers, wordt er dan gekeken naar van wij zijn een internationaal bedrijf dus wij doen alles in het Engels

- IR: Ja een andere focus zou misschien om het iets kleiner te houden, bijvoorbeeld kijken hoe het in het Nederlands gebeurt en dan kijken hoe het in één andere taal gebeurt, bijvoorbeeld Frans of bijvoorbeeld Engels, en dan zien van (...) Dan zal ik dat proberen verder uit te werken $e h$, ja

- IR: Yes, but indeed, I can so yes (...) based on this interview I have to come up with a kind of proposal that is not set in stone yet, but shows what direction I would like to go into, so I think it could be really interesting to, yes, about those different channels in crisis communication setting uhm how companies then go about things. I haven't yet (...)

- IE: How they fluctuate within one and the same language then

- IR: Yes yes

- IE: and and which languages are stuck to based on which criteria

- IR: Yes

- IE: will you be looking into followers, will you be looking at we're an international company so we do everything in English?

- IR: Yes. A different focus might then be to keep it a little smaller, for example how it is done in Dutch and to then look at how it

happens in one other language, like for example French or English for example, and to then look at (...) I would then try to further analyse that uhm, yes

Note that in this extract the interviewer's repeated use of so-called continuers - for example, repetition of "yes" - encouraging the interviewee to carry on, is very much in line with the advice that is given to researchers on how to conduct semi-structured interviews.

\section{The Interviewer as Practitioner}

A third and final group of interviewers approached the informants from a practitioner perspective, drawing on a professional vocabulary, and 
displaying low formality and a high degree of agency. In the following extract, swift turn switches and a more or less equal distribution in the amount that each party is contributing to the conversation create the impression of a smooth interaction between colleagues and not of a student-practitioner interview.

Extract 12:

- IE: Ik ben wel niet de eigenaar van [de organisatie] hé, dus ik weet niet euh

- IR: nee, dat is normaal niet erg ... ja normaal is dat, alé geen probleem. Euhm ... ja, het eerste deeltje gaat dus over uzelf, euhm, en dat gaat dus gewoon ... wat is uw functie binnen de organisatie?

- IE: Euh showroom manager

- IR: Ja, en welke taken houdt dat dan precies in?

- IE: euhm dus showroom beheer, euh ontvangst van stylisten, euhm en verder ook, ja communicatie, euh de planning, euh naar klanten toe, euh Instagram onderhouden en, $j$ a allerhande taken

-IR:Ja, euh en daarvoor, welke achtergrondhebjezo qua opleidingenjobsdieje-

- IE: Communicatiewetenschappen

- IR: Ahja. En dat is uw eerste job hier? Of heb je daarvoor-

- IE: Euh neen. Ik heb al euhm in een architectenbureau gewerkt voor de communicatie te onderhouden, en daarnaast heb ik ook al voor iemand gewerkt die euh magazines maakte, euhm en nog voor een journalist heb ik ook al gewerkt.

- IE: I am not the owner of (company), you know, so I don't know uhm

- IR: No, that should not matter normally ... yes, normally that is, you know, not a problem. Uhm ... yes, the first little part is about you, uhm, and that is just about ... what is your job within the organization?

- IE: Uhm showroom manager

- IR: Yes, and which tasks does that comprise?

- IE: uhm so showroom management, uhm hosting stylists, uhm and furthermore also yes communication, uhm, planning, uhm towards customers, uhm updating Instagram, and yes various tasks

- IR: Yes, uhm, and before that, what is your background, when it comes to education and jobs you

- IE: Communication sciences

- IR: Oh right. And that is your first job here? Or did you before

- IE: Uhm no. I have already uhm worked at an architecture agency maintaining communication, and next to that I have also worked for someone who made uhm magazines, uhm and also for a journalist I have worked as well 
The following is perhaps even clearer. Here the student sounds very informal indeed, with the use of the direct, informal second person address ("vindt ge" instead of "u"), of substandard forms ("da" instead of "dat") and of a more relaxed vocabulary that deviates substantially from the script that the student had been provided with (e.g. the use of 'strubbelingen').

\section{Extract 13:}

- IR: Ik ga misschien nog vlug efkes overgaan naar het persoonlijke deel, want $i k$ denk dat we al redelijk goeie antwoorden daarop hebben. Uw persoonlijk visie op vreemde talen in organisaties, vindt ge da leuk, persoonlijk, om Engels te praten hier als die, eh, Spaanse Erasmusstudent hier is? Vindt ge da verrijkend ook voor iedereen of ziet ge dat eerder, misschien, als een bedreiging, niet persoonlijk voor u dan, maar voor andere mensen die misschien niet iets minder Engels kunnen? Denkt ge dat daar wat strubbelingen kunnen door ontstaan of niet?

- IR: Maybe I'll just quickly go to the personal part, 'cause I think we have a few really good answers there. Y'r personal take on foreign languages in organizations, d'ya like that, personally, to speak English here if that uhm Spanish Erasmus-student is here? D'ya think it's enriching also for all of you or d'ya see it more, maybe, as a threat, not to ya personally that is, but to other people who maybe speak a little less English? D'ya think that problems may arise because of that or not?

It should be noted that the three personae sketched above do not constitute fixed and clearly delineated categories. On the contrary, we believe that there is a continuum of identity construction with some students in the same category identifying to a greater or lesser extent with a particular persona than others. In some cases, there is even an evolution in the course of the 30-minute interview with some interviewers starting out very much as students and gradually embracing a researcher or practitioner persona; it would be interesting to look at what role the interviewer plays in this.

What is perhaps most striking about our findings is that they seem to correspond with what came out of our previous work on how to bridge the classroom and real-world practice in the area of business and professional communication (Vandendaele et al. 2016). Based on our analysis 
of the interactions between students, academic staff and professionals in the context of student research projects commissioned by external organizations, we pointed to the challenges involved in bringing together the worlds of learning, scholarship and practice. It is exactly these three worlds that are represented in the different personae we presented above. The present analysis has also demonstrated that it is the same two parameters, viz. freedom and mutuality, that seem to distinguish them, with the researcher persona showing more freedom (e.g. vis-à-vis the script to be followed) than the student persona and the practitioner persona showing more mutuality (e.g. partnering up with the interviewee).

\section{Conclusions}

It is time to return to this volume's central question and reflect on what we can learn from the case presented here as to what counts as data in the study of business and professional discourse.

Clearly, our collective data-gathering efforts by means of student-led interviews have generated substantial diversity, with the students slipping into different personae as they go about their interviewing assignment. It is simply unrealistic to expect that each interviewer will be presenting each question in exactly the same way to each interviewee. And even if it was not, there would be no way in which we could expect the interviewees to co-construct the interviews in exactly the same fashion (cf. Briggs's Learning how to ask (1984). We believe that, as researchers, we need to be aware of this so-called 'inter-interviewer variation' and that, if we are, we can actually embrace it as an "asset". In our view, genuine awareness of this diversity implies taking the contextualization of our research efforts very seriously: in proceeding towards the analytical stage, we need to recognize that the interviews are deeply embedded in the program's traineeship efforts and to acknowledge the power dimension involved in this. This includes mapping how students behave in the process of negotiating access, gaining trust and constructing a professional identity for themselves (one that may or may not be in conflict with their role as students/ researchers). 
Crucially, it can be argued that all of this does not just apply to the collective data-gathering efforts by means of student-led interviews that we have pursued in the research reported here; it applies to the study of business and professional discourse in general. Variation and diversity are intrinsic features of most data that can be gathered in this field, whether we involve our students or not. And coming to grips with the essential contextedness of all business and professional discourse is a key requirement, no matter if we explore issues of multilingualism in Belgian organizations or something completely different. Any data, including audio and video recordings, interview transcripts or the results of survey research, are deeply and unavoidably embedded in the organisational context where they originate, and they are bound to entail profound power asymmetries that impact on what people say or write. It follows that standardized data (where data are perfectly comparable across settings) is not just a myth in business and professional discourse studies; it is not even desirable. Instead, the intrinsic diversity of the discursive repertoire constitutes a rich basis for analysis in its own right.

All of this points to at least one implication for how students, scholars and practitioners can work together in researching the multilingual workplace, one that can be taken to serve as a guideline in order to strengthen interaction between them: we should try to make our students aware of the different personae they may be slipping into as they gather (interview) data for the study of business and professional discourse. This could include analysing interview transcripts together, something that will help them on the exciting path from learning to practice that we have described elsewhere before.

Let us end this chapter by circling back, once more, to the question "What counts as data?" in the study of business and professional discourse, in general, and to one of the key notions spelled out in the introduction to this volume, viz. that of background and the question how familiar we need to be, as analysts, with the data that we are studying. In the context of our case study, the latter ties in with that other key notion authenticity: since the data gathering was subcontracted to the students, it could be argued that the data discussed in this study are-from the analysts' point of view at least-second-hand, hence not 100 percent authentic as there is a gap between the researchers and the practitioners 
that prevents us from reaching a deep understanding of what is going on in the interviews. While we believe these reservations make sense, we would like to argue that they call for a more comprehensive discussion on how researchers can collaborate and share results, and on how researcher positioning is affected. These questions are especially pertinent when it comes to the complex interactions between scholars, learners and practitioners, where-we have seen-identities are fluid and boundaries get blurred: as students put on researchers' hats while proceeding on the path towards practice, no one's perspective on the data can simply be taken for granted and the scholar-researcher-practitioner arena becomes an object worthy of study in its own right.

\section{References}

Aertsen, T., Jaspaert, K., \& Van Gorp, B. (2013). From theory to practice: A crisis simulation exercise. Business Communication Quarterly, 76, 322-338.

Allan, K. (2013). Skilling the self: The communicability of immigrants as flexible labour. In e. A. Duchêne, M. Moyer, \& C. Roberts (Eds.), Language, migration and social (in)equality: A critical sociolinguistic perspective on institutions and work (pp. 56-78). Bristol: Multilingual Matters.

Angouri, J. (2013). The multilingual reality of the multinational workplace: Language policy and language use. Journal of Multilingual and Multicultural Development, 34, 564-581.

Antaki, C. (2011). Applied conversation analysis: Intervention and change in institutional talk. New York: Springer.

Bargiela-Chiappini, F., \& Harris, R. (1997). The languages of business: An international perspective. Edinburgh: Edinburgh University Press.

Blake, B. L. (1991). Student research in the classroom: Solving the teacher/ researcher dilemma. Business Communication Quarterly, 54, 73-75.

Briggs, C. (1984). Learning how to ask: Native Metacommunicative competence and the incompetence of fieldworkers. Language in Society, 13, 1-28.

Bruyer, T., Jacobs, G., \& Vandendaele, A. (2016). Good pharma? How business communication research can help bridge the gap between students and practitioners. Business and Professional Communication Quarterly, 79, 141-153.

Drew, P., \& Heritage, J. (1992). Analyzing talk at work: An introduction. In P. Drew \& J. Heritage (Eds.), Talk at work. Interaction in institutional settings (pp. 3-65). Cambridge: Cambridge University Press. 
Drury-Grogan, M. L., \& Russ, T. L. (2013). A contemporary simulation infused in the business communication curriculum: A case study. Business Communication Quarterly, 76, 304-321.

Ehrenreich, S. (2010). English as a business lingua Franca in a German multinational corporation: Meeting the challenge. Journal of Business Communication, 47, 408-431.

Grin, F. (2013). Language policy, ideology and attitudes: Key issues in Western Europe. In R. Bayley, R. Cameron, \& C. Lucas (Eds.), The Oxford handbook of sociolinguistics (pp. 629-650). Oxford: Oxford University Press.

Handford, M. (2017). Corpus linguistics. In B. Vine (Ed.), The Routledge handbook of language in the workplace. Abingdon: Routledge.

Harzing, A.-W., Köster, K., \& Magner, U. (2011). Babel in business: The language barrier and its solutions in the HQ-subsidiary relationship. Journal of World Business, 46, 279-287.

Haugh, M., \& Watanabe, Y. (2017). (Im)politeness theory. In B. Vine (Ed.), The Routledge handbook of language in the workplace (pp. 65-76). New York: Routledge.

Heller, M. (2010). The commodification of language. Annual Review of Anthropology, 39, 101-114.

Jacobs, G. (1999). Preformulating the news: An analysis of the metapragmatics of press releases. Amsterdam/Piladelphia: John Benjamins Publishing.

Kerekes, J. (2017). Language preparation for internationally educated professionals. In B. Vine (Ed.), The Routledge handbook of language in the workplace (pp. 413-424). New York: Routledge.

Lønsmann, D. (2014). Linguistic diversity in the international workplace: Language ideologies and processes of exclusion. Multilingua-Journal of Cross-Cultural and Interlanguage Communication, 33, 89-116.

Lüdi, G. (2017). Identity in the workplace in a context of increasing multilingualism. In B. Vine (Ed.), The Routledge handbook of language in the workplace (pp. 348-360). New York: Routledge.

Mayr, A. (2008). Language and power: An introduction to institutional discourse. A\&C Black.

Mortensen, J. (2014). Language policy from below: Language choice in student project groups in a multilingual university setting. Journal of Multilingual \& Multicultural Development, 35, 425-442.

Östman, J. O., \& Verschueren, J. (Eds.). (2011). Pragmatics in practice (Vol. 9). Amsterdam/Philadelphia: John Benjamins Publishing. 
Peltokorpi, V., \& Vaara, E. (2014). Knowledge transfer in multinational corporations: Productive and counterproductive effects of language-sensitive recruitment. Journal of International Business Studies, 45, 600-622.

Rampton, B., Tusting, K., Maybin, J., Barwell, R., Creese, A., \& Lytra, V. (2004, December). UK linguistic ethnography: A discussion paper. In UK Linguistic ethnography forum (pp. 1-24).

Robertson, R. (1994). Globalization or glocalization? Journal of International Communication, 1, 33-52.

Sarangi, S., \& Candlin, C. N. (2010). Applied linguistics and professional practice: Mapping a future agenda. Journal of Applied linguistics and professional practice, $7,1-9$.

Thurlow, C. (2020). The business of words. London: Routledge.

Vandendaele, A., Bruyer, T., \& Jacobs, G. (2016). We never even wondered whether we trusted them or not: From freedom to mutuality in a student research project. In G. M. Alessi \& G. Jacobs (Eds.), The ins and outs of business and professional discourse research : Reflections on interacting with the workplace (pp. 102-116). London: Palgrave Macmillan. 